\title{
The Spectacular Rise and Disastrous Collapse of a Financial Scheme: The Case of Albania
}

\author{
Edlira Thanasi, Joseph Riotto \\ New Jersey City University, Jersey City, USA \\ Email: jriotto@njcu.edu
}

How to cite this paper: Thanasi, E. and Riotto, J. (2017) The Spectacular Rise and Disastrous Collapse of a Financial Scheme: The Case of Albania. Open Journal of Business and Management, 5, 194-207. http://dx.doi.org/10.4236/ojbm.2017.51018

Received: September 21, 2016

Accepted: January 21, 2017

Published: January 24, 2017

Copyright $\odot 2017$ by authors and Scientific Research Publishing Inc. This work is licensed under the Creative Commons Attribution International License (CC BY 4.0).

http://creativecommons.org/licenses/by/4.0/

\begin{abstract}
This study discusses the similarities and differences between Ponzi and Pyramid schemes and the unparalleled example of Albania. In particular, this document treats the creation and collapse of a financial scheme in Albania, which had some characteristics of both Ponzi and Pyramid schemes, based on their definitions and examples. The study points out the factors that caused the creation of some financial intermediary entities in Albania, which resulted to be a massive fraudulent scheme; how they were developed; and the consequences for the country in terms of economic, political and social environment after they collapsed. The Case of Albania is an unprecedented case of a fraudulent financial scheme due to the magnitude of the population involved (57\%) relative to the country's economic size (liabilities of the scheme reached the equivalent of $51 \%$ of GDP); the chaos and the near civil war state as a result of the population's violent protest; the state's measures taken by the governments after the ruin of the economy; the quick recovery; and the process of reducing the impacts of the financial scheme collapse in the long run.
\end{abstract}

\section{Keywords}

Ponzi, Pyramid Schemes, Population Involvement, Ruin of the Entirely Economy, Quick Recovery

\section{Introduction}

U.S. Securities and Exchange Commission (SEC) through "Ponzi schemes" section (n.d.) [1] provides the following definition for Ponzi schemes: "A Ponzi scheme is an investment fraud that involves the payment of purported returns to existing investors from funds contributed by new investors".

According to SEC, "Beware of Pyramid Schemes" (2013) [2]: "Pyramid schemes are a type of fraud in which participants profit almost exclusively through recruiting other people to participate in the program". 
As Ponzi and pyramid schemes are closely related, these two terms are usually used interchangeably, while treating a fraudulent financial scheme. For instance, some authors refer to the fraudulent scheme in Albania in 1997, as Ponzi schemes (Bezemer, 2006, pp. 18; Trumbore, n.d.) [3] and some others as Pyramids schemes (Jarvis, 1999; Taylor, 2012) [4] [5].

The similarities consist of both schemes promising extraordinary returns on investment capital. They offer sustainable "earnings" and are self-supporting as long as the number of investors increases and cash outflows match cash inflows.

They typically encourage investors to reinvest their profits and rely on new investors/participants to meet obligations to prior investors.

Ponzi scheme and Pyramid scheme will have both the end of being insolvent.

Even though they are closely related, as they both involve paying longer-standing members with money from new participants, instead of actual profits from investing or selling products to the public (U.S. Securities and Exchange Commission, n.d.) [1], they have differences in the terms of structure and type of products that the schemers offer to their clients (U.S. Securities and Exchange Commission, (n.d.) [1] (Table 1).

\section{Ponzi Scheme}

A Ponzi scheme is a fraudulent investment management service, ran and controlled by a central operator ("portfolio manager"), who will pay promised profits to the older investors by using the capital of new investors joining the scheme.

Ponzi schemes are named after Charles Ponzi, who in early 1920 offered investors a choice between a $50 \%$ return on a 45 -day investment and a $100 \%$ return on a 90 -day investment due to an arbitrage in the pricing of international reply coupons, claiming that the high profits were results of his unique understanding of the international postal reply coupon system (Branscum, 2002) [6].

A Ponzi scheme is always illegal. The operation does not generate any income actually and the funds collected will not be invested, even though it may seem legitimate

Table 1. Differences between pyramid scheme and Ponzi scheme.

\begin{tabular}{|c|c|c|}
\hline & Pyramid Scheme & Ponzi Scheme \\
\hline Typical "hook" & $\begin{array}{l}\text { Earn high profits by making one payment } \\
\text { and finding others to become distributors } \\
\text { of a product. The scheme typically does not } \\
\text { involve a genuine product. The } \\
\text { purported product may not exist or } \\
\text { it may be "sold" only to other people } \\
\text { who also become distributors. }\end{array}$ & $\begin{array}{l}\text { Earn high investment returns with little } \\
\text { or no risk by simply handing over your } \\
\text { money; often the investment does not } \\
\text { exist or only a small percentage of } \\
\text { incoming funds are actually invested. }\end{array}$ \\
\hline Payments & $\begin{array}{l}\text { Must pay a one-time or recurring } \\
\text { participation fee and recruit new } \\
\text { distributors to receive payments. }\end{array}$ & $\begin{array}{l}\text { No recruiting necessary } \\
\text { to receive payments. }\end{array}$ \\
\hline $\begin{array}{l}\text { Interaction with } \\
\text { original promoter }\end{array}$ & $\begin{array}{l}\text { Sometimes none. New participants may } \\
\text { enter the pyramid scheme at different levels. }\end{array}$ & $\begin{array}{l}\text { Promoter generally interacts } \\
\text { directly with all participants. }\end{array}$ \\
\hline $\begin{array}{l}\text { How the scheme } \\
\text { works }\end{array}$ & $\begin{array}{l}\text { Funds from new participants are used to pay } \\
\text { recruiting commissions to earlier participants. }\end{array}$ & $\begin{array}{l}\text { Funds from new investors are used to } \\
\text { pay purported returns to earlier investors. }\end{array}$ \\
\hline Collapse & $\begin{array}{l}\text { Fast. An exponential increase in the number } \\
\text { of participants is required at each level. }\end{array}$ & $\begin{array}{l}\text { May be relatively slow if existing } \\
\text { participants reinvest money. }\end{array}$ \\
\hline
\end{tabular}

Source: U.S. Securities and Exchange Commission, (n.d.) [1]. 
and profitable. The Ponzi schemer will only ask the investors to invest in something that will generate extraordinary high returns due to his/her unique "amazing" skills and investment strategies, which are usually ambiguous. The "portfolio manager" doesn't provide too much detailed information about investment strategies, claiming as doing so to "protect" the business. The promoter will take the money from investors with the promise to take care of the rest and reward in a later moment. The schemer "reports" periodically to the investors on how much they are making in their "investment" when in fact there is no real profit.

To avoid having too many simultaneous withdrawals from the investors, Ponzi schemes encourage them to stay in the game as the only way to make more money and trying at the same time to attract new funds, hiding the fraud as long as possible. If the payout to the investors is moderate, the scheme can "survive" for several years but it will eventually collapse.

The Ponzi scheme will deteriorate when: 1) the central operator takes the remaining invested money and runs; 2) new investors cannot be easily found, meaning there is no more cash flowing in; 3) a high number of investors start withdrawing their initial capital invested and the interest earned (Yang, 2014) [7].

\section{A Hypothetical Example of How a Basic Ponzi Scheme Operates}

The Ponzi promoter raises $\$ 1,000,000$ in funds and promises an annual return of $20 \%$ (very alluring in the current yield environment). At the end of the year, the central operator has to pay to the investor $\$ 1,200,000$ so the promoter has to find another investor before the year ends, with the same promise of returns, but requesting an initial capital of $\$ 1,200,000$ from the new investor. If the investor agrees with the proposed conditions and enters the scheme, the operator takes the money and pays off the first investor (Jory \& Perry, n.d.) [8].

According to Taylor (2012) [5], a scheme can last usually at maximum for ten years, even if no one of the investors claims the funds back.

And since it doesn't make sense in taking the risk to go in jail without getting rich, the promoter tries to find as many investors as possible and pockets some of the money for himself, in the form of a fee or by stealing them.

Ponzi schemes have been run by hundreds of promoters across the world and usually have had an unpleasant end.

One of the most distinguishable and notorious Ponzi schemes in the American History is the one "composed" by Bernard Mad off with an estimated cost of the scheme out of $\$ 65$ billion and involving approximately 8000 investors. In Mad off's case, things began to go bad after investors demanded a total of $\$ 7$ billion back in returns, while Madoff, only had \$200 - \$300 million to give (Yang, 2014) [7].

\section{Pyramids Scheme}

A pyramid scheme is a business model (not necessarily an investment) that involves promising investors or participants mainly for recruiting other people into the scheme. Pyramid scheme is not necessarily a fraudulent or illegal investment, though it is fre- 
quently associated with deceivable investment schemes offering remarkable returns that are impossible to achieve by any possible investment opportunity. Basically, new investors/participants pay money to the founder or other participants who became part of the scheme in an earlier stage than currently involved members. As Clark and McGrath (n.d.) [9] state that the Pyramid scheme offers the members the chance to make money by themselves by providing stimulus in the form of a great investment opportunity, such as the right to sell a certain item or the right to buy a franchise and recruiting more people in an exponential growth. Each member pays a "commission" to the person who recruited them for the given opportunity to sell the product or becoming part of the franchise and the funds collected from members is divided with those at the higher levels of the pyramid structure. Clearly, it is a fund transfer to the earlier joiners of the scheme and neither real asset does exist nor real profit is generated.

\section{A Hypothetical Example How a Pyramid Scheme Works}

The pyramid scheme follows a Geometric Progression. Each person in the scheme has to recruit two other people under them, who each pays $\$ 100$, each of the recent joiners must recruit two more people who pay $\$ 100$, to cover the initial "investment". The four members need to find eight new participants and so on. But this cannot continue endlessly as the number of people in the world is limited and the last generation will lose all the money. The scheme is intrinsically deceitful because since in its original point its liabilities surpass its assets and the scheme will collapse in a certain time, sooner than a Ponzi scheme (Taylor, 2012) [5].

A real-life example of a pyramid scheme is Wealth Pools International case, for which SEC acquired an asset freeze in December 2007. Wealth Pools pretended to be a marketing company selling English and Spanish language DVDs through a global network of sales associates. New participants purchased a set of DVDs which they would then try to resell for profit. However, participants profited by recruiting new sales associates, rather than by selling DVDs. The scheme affected 70,000 people in 64 countries and cost participants $\$ 132$ million in 2007 alone (U.S. Securities and Exchange Commission, 2007) [10].

\section{A Bitter Story from the Past}

The seed of a famous and interesting Pyramid scheme can be found as early as in the eighteenth century in France close to the end of King Louis' XIV reign (1643 to 1715), while the France's economy was suffering a sharp decline. According to Sales (2007) [11], this is the first historical example of a Pyramid Scheme. The country owed 3 billion livres of debt and the government's bankruptcy was widely discussed among the officials. Politicians on the other hand, scared the revolution and looked instead for a more appropriate and acceptable solution. The first attempt to "fix" the problem was by creating new gold and silver coins, having the same face value with the coins in circulation but weighing $20 \%$ less than those, and the public was obliged by the power of law to make the exchange. The extra gold and silver saved from the new coins was planned to be used for paying the country's debt. People of France denied exchanging their valuable gold and silver for less value. This frustrating scheme highly belittled the gov- 
ernment of France and deepened the recession.

Scottish economist John Law was appointed by Regent Duc d'Orleans as Controller General of France. After King Louis' XIV death and together built a bright scheme to pay off the debt.

Firstly, the Regent of France "blessed" Law's initiative to constitute a central bank under the name of Law and Company; secondly the Regent Authorized Law's bank to issue bank notes that would have been accepted for the payment of taxes. Lastly, he made his wise movement by publicly announcing that his "paper money" could be exchanged for their face value in gold or silver, giving the perception that these "bank notes" are as good as gold or silver coins.

The purpose of the scheme was to make people believe in the trustworthiness of Law's bank and with his noticeable banking experience was able to convert the notes in coins, with no need to show the gold or silver anymore.

As people transacted their gold for paper, the bank's vault filled with gold, which was used to issue loans in paper money. The genuine product "gold and silver" disappeared and the fake product, "paper money", came into light.

The Regent declared Law's bank as the Royal Bank of France and made it a publicly-traded company, so people had the opportunity to buy stocks in the government's bank and received bank loans. As time went by, the emission of the paper currency to the public from the bank overlapped the one billion livres (the bank became a pyramid scheme).

On the other hand, foreign countries requested that payments should be made in gold and silver and didn't accept the paper currency. The gold and silver started to stream out of France into the other countries, causing the perception to the population that the gold and silver backing their paper money was vanishing, so it began a massive exchange of paper money into gold and silver coins. In efforts to stop the shrink of the gold and silver reserves, the government devaluated the value of the coins with $10 \%$ below the paper and limited the amount of coins one individual could receive, affirming that the intrinsic value of gold and silver was below of the paper money.

February, 1720 sealed the end of John Law' fraudulent scheme! In efforts to hold gold and silver, an order was issued from the government (having Law's signature), which prohibited anyone to hold more than 500 livres in coin and banned the population to buy precious jewelry. This was a slap in the face for the irritated public!

In May, 1720 the bank had empty vaults of gold and silver and couldn't make any payment in coins anymore. The scheme finally broke down.

In this story, the government, using its authority, tried to create money with no production at all and deceived the public making them to believe paper money has the same value as gold, but a legitimate business is always based in product/service creation and added value for the society.

\section{The Case of Albania}

Ponzi and Pyramid schemes became "de rigueur" in many former communist countries as they cuddled capitalism. According to Christopher Jarvis (1999) [4]: "The scope of Albania's pyramid scheme was unprecedented; at its height, the nominal liability 
amounted to almost half of the country's GDP. Many Albanians, about two-thirds of the population, invested in them."

While some authors refer to the Albanian's scheme as Ponzi schemes (Bezemer, 2006, pp. 18, Trumbore, n.d.) [3] [12] and some others refer to them as Pyramids schemes (Jarvis, 1999, Taylor, 2012) [4] [5], we have noticed that the fraudulent financial scheme in Albania has some similarities of both Ponzi and Pyramids scheme.

Why Ponzi scheme? Because the companies offered a) an extremely high rate of return in a short period of time; b) most of them didn't make real investment of the funds collected from the people; c) they were run by a central promoter that kept the "investment strategies" in darkness.

Why Pyramids? a) Initially, not all the companies in Albania were illegal and fraudulent; b) some of the companies made some real investments in the country, mainly their focus was concentrated at the real estate area; c) the promoter hired people to interact with the participants; $d$ ) since in the starting point, liabilities exceeded assets.

Based on the information provided above, fraudulent schemes in Albania seem to be a combination of Ponzi and Pyramids schemes and we would refer to the Albanian scheme as "Ponpyra" scheme.

\section{Ante "Ponpyra" Climate}

Albania had been under the heel of the communist dictatorship of Enver Hoxha for four decades. He ruled the country with an iron fist and at that time land was confiscated and the dictator rigidly prohibited any form of the private enterprise and property. As the Albania leader wrote in one of the many volumes of memoirs "Let everyone understand clearly, the walls of our fortress are of unshakeable granite rock", (Saxon, 1985) [13], he made sure to keep the country self-isolated from the rest of the world's information and influences.

Until the year of 1976, the banking system was conducted by only one Bank (State Bank of Albania) which operated as the Monetary and Lending Authority in the country.

In 1990, the tinny European country began the process of transition from dictatorship and a centralized economy to democracy and at 91's this poor country advanced with fast and firm steps the approach to an open market economy, holding no financial market and rudimentary banking experience in its shoulders.

The banking system was limited. In 1992 two-tier banking systems was introduced and Bank of Albania (Central Bank, previously named State Bank of Albania) was established. Only three state owned capital banks and two banks with joint capital (Albanian government's and foreign capital) were operating at the time. In the following years, a few small privately-owned banks were created, when in 1993, Kosovo's government bank was created and in 1996, two Greek capital base banks were licensed (Cani \& Hadëri, 2002) [14].

The state owned capital banks held $90 \%$ of the total deposits and $88 \%$ of the domestic loans, offering real positive yields on deposits, but they performed a very restricted financial intermediary activity and had high portion of bad loans in their portfolios, making them subject of credit ceiling set from Bank of Albania. The limited number of 
commercial banks operating in the country didn't show any interest in attracting consumer deposits and were more focused in performing foreign exchange and trade finance transactions. Furthermore, the low level of the lending activity in the economy, as an inefficiency of the banking system, encouraged the lack of the financial intermediary function from the banks.

This environment offered a brilliant opportunity for some financial intermediaries to enter the financial market.

\section{Scam Blossom}

While banks couldn't satiate the private sector appetite for credit and taking advantage of the deficiencies in the regulatory framework, informal lending companies developed swiftly. Their activity was based on accepting funds from the public and offering high tempting yields.

They reached their peak in 1996, when in January top largest companies paid on monthly basis an average interest rate of $5 \%$ (100\% on annual basis). Competing for funds and trying to attract more "victims" they hiked the interest rate at $8 \%$ (monthly). In early 1996, two new "money collectors" Xhaferri and Populli were created, in the following months. These two companies accounted for approximately 2 million contributors out of a population of 3.5 million and with another "ghost" company, Sude that operated in illegality for almost 3 years and had no real investment at all, at that time they offered an interest rate that reached an average monthly rate of $16 \%$.

In September of 1996, yields offer stroke magic level of 30\% in a month, while in November, Sude made irresistible offers on doubling principal in two months and by the end of the year, the nominal value of the scheme' liabilities reached the level of $\$ 1.2$ billion (Jarvis, 1999) [4].

By the year of 1996, 25 "greedy operators" that were running the country (Table A4).

\section{Why a Large Scale of Population Involvement?}

In fact, "Communism was a great system for making people equally poor" (Friedman, 2007, pp. 52) [15] and people in Albania were eager to become rich in a fast pace during the transition to capitalism. As these companies came into life since in early 90's, they rewarded some of the contributors with ample payments. People spread the word of mouth between family member and relatives inside and outside the country. Even it was believed that the high returns came from criminal activities in which some of the companies were engaged, people ignored this and thought that even this illegal source of generating money, would helped the embryonic economy of the small Albania to grow. Furthermore, they were inexperienced with the financial market concepts and didn't perceive the risk associated with their investment. Missing any past failure and coming from socialist heritage, where the "government and/or leader provided income, work, education and health services to its citizens, the population was unable to perceive that the government couldn't serve as a guarantee for the schemes." (Elbirt n.d., Cani \& Hadëri, 2002) [14] [16].

In addition, there was a huge publicity in media for these schemes which was helped with the endorsement of the government and politicians to these financial bubbles 
(there were claims among the people that some government official received favorable "treatments" from these firms). The government support was implied by not demanding these firms to pay taxes or to initiate a fiscal evasion investigation towards them. Another case that makes government a passive spectator, was when one of the largest company VEFA deposited in the banking system an amount of $\$ 120$ million (5\% of GDP), transactions discovered and reported from the Bank of Albania and even though consistent alerts were sent to the Ministry of Finance from the IMF and the World Bank, this Ministry did not warn the public about the fraudulent schemes until October (Jarvis, 1999) [4].

People ran to sell their houses and "invested" all of the money; capital injected from outside the border either in a form of a debt required from family member inside the country or invested by immigrants on their behalf by family members, farmers sold their livestock and deposited the money in the firms.

Remittances present an interesting scenario; in that, in the year 1996 the remittances of Albanian immigrants through the parallel market were $\$ 440$ million $(35.4 \%$ increase from 1995) or $18.6 \%$ of GDP. In the following year, 1997, the remittances of Albanian immigrants through the parallel market dropped to $\$ 183$ million (58.4\% decrease from 1996) or $11.6 \%$ of GDP (Karafolas \& Konteos, 2010) [17] (Table A3). According to statistics from the Bank of Albania Annual Report of 1998, only 43\% went through the banking systems; therefore, the majority (57\%) went outside the banking system in the form of cash (Banka \& Shqipërisë, 1999) [18].

\section{Bubble Burst}

The first firm that declared bankruptcy was Sude (the "ghost" firm that didn't make a single real investment in the country), breaking public's confidence for all the companies. There were some desperate attempts from the largest companies to gain back people's trust with lowering the monthly interest rates, but this action didn't help the deposit's sewerage. In January 1997 two of the large firms went bankrupt, followed by other schemes that were unable to make payments to the public, causing a lot of angriness to the people. Government refused to indemnify the depositors (Table A5) and blocked the bank accounts of two companies, amounts that were translated in $10 \%$ of country's GDP. On the other side, Bank of Albania took its own initiative by setting maximum thresholds on daily funds withdrawals from the bank accounts, preventing other firms to drain their accounts (Jarvis, 1999) [4].

By March 1997, Albania's turmoil reached catastrophic size and was close to a civil war. Most of the military and police forces deserted, allowing the people to access the buildings and grabbing 1 million weapons. The government tried to stabilize the South of Albanian that initialized the violent protest, but police officers were killed macabrely by the irritated people and got totally out of the government's control. The angry individuals burned customs posts and tax offices, not only disappearing all the records but making impossible for the government to exist without any source of revenues. Many prisoners were released, surprisingly even from abroad (Greece), pouring more fuel to the fire. There were some claims at the time that Greece was taking advantage from the chaotic situation created in Albania to satisfy its historical appetite to "engulf" some 
territories in the Southern Albania and there are claims that Turkey would have interfered if this scenario would had happened.

Schools were closed and the country was paralyzed. A large number of Albanians emigrated and foreign nationalities were forced to forsake the country. The government lost its power to most of the cities and the resignation was inevitable.

The country was in anarchy condition and order was established with the help of the United Nations, which sent 7000 troops in April 1997. New parliamentary elections were held on end June and a temporarily coalition government was created.

\section{Ruins from Disaster}

During the turbulences of 1997, as Halili (2013) [19] states at News Agency Today News, "approximately 3500 people were killed (360 police-officers), 5000 people were injured and the damage on country's physical assets was around \$200 million”.

The schemes swallowed around $\$ 1.2$ billion savings, while the average wage on a monthly basis was $\$ 80$ (Halili, 2013 \& Taylor, 2012) [5] [20]. Some of the promoters run away with the money and some of them were jailed.

The political and economic crisis has started since in 1996, but shattered after the schemes collapsed. As Cani \& Hadëri discuss (2002) [14], inflation increased at the level of $42 \%$ (92 - 96, inflation was $17.5 \%$ on average), output fell to 7\% (from 1992 to 1996 the average annual growth was $9 \%$ ), while budget deficit increased and current accounts of balance of payments worsened dramatically. In the middle of 1997 the Albanian Lek was depreciated almost $100 \%$. In the second half of 1997, the new government with the assistance of the World Bank Group and IMF, applied a post-crisis program and deepened the structural reforms in the banking industry. For reducing the fiscal deficit, the government increased VAT in $20 \%$ (putting pressure on price increase) and reduced the public sector' wages significantly.

A crucial part of the program was the administration and liquidation of the fraudulent schemes, duty that was assigned to foreign international accounting firms. The liquidation process was not successful as it took too long for the administrators to gain control to their tasks and most of the companies' liquid asset had already scaled down.

Even though the schemes' collapse had negative impacts in all over the country, it had effects in the short term, reducing a possible expansion in the long term. One of the most important factors that helped the country to recover sharply was the courageous decision from all the Albanian governments not to pay back the depositors from the state budget (Jarvis, 1999, Cani \& Hadëri, 2002) [4] [14].

\section{Conclusions}

Ponzi and pyramids schemes have an early existence and have spread over the years in different forms and countries. The Albanian case was a highly destructive scheme because of the size of the population's and government enrollment in these schemes and the near civil war explosion causing enormous social, economic, political and reputational damages for the last country in Europe that down the communist wall.

Lack of financial market experience and information, weaknesses in governmental leadership, the absence of a complete legal framework and the inappropriate inherited 
public's expectations were factors that established the foundation stones of the spectacularly destructive scheme.

\section{References}

[1] U.S. Securities and Exchange Commission (n.d.). Ponzi Schemes. https://www.sec.gov/answers/ponzi.htm

[2] U.S. Securities and Exchange Commission (2013) Beware of Pyramid Schemes Posing as Multi-Level Marketing Programs. http://www.sec.gov/investor/alerts/ia pyramid.htm

[3] Bezemer, D.J. (2006) On Eagle's Wings: The Albanian Economy in Transition. Nova Science Publishers Inc., New York, 18-19.

[4] Jarvis, C. (1999) The Rise and Fall of the Pyramid Schemes in Albania. IMF Working Paper, 99/98, 1-35. https://doi.org/10.5089/9781451852127.001

[5] Taylor, S. (2012) Ponzi and Pyramid Schemes [Blog Post]. http://www.simontaylorsblog.com/2012/09/02/ponzi-and-pyramid-schemes/

[6] Branscum, B.E. (2002) Ponzi v. Pyramid; A Comparison. http://www.fraudsandscams.com/ponzipyramid.htm

[7] Yang, S. (2014) 5 Years Ago Bernie Madoff Was Sentenced to 150 Years in Prison-Here's How His Scheme Worked. Business Insider. http://www.businessinsider.com/how-bernie-madoffs-ponzi-scheme-worked-2014-7

[8] Jory, S.R. and Perry, M.J. (n.d.). Ponzi Schemes: A Critical Analysis. Journal of Financial Planning. https://www.onefpa.org/journal/Pages/Ponzi\%20Schemes\%20A\%20Critical\%20Analysis.as $\underline{\mathrm{px}}$

[9] Clark, J. and McGrath, J. (n.d.) How Ponzi Schemes Work. http://money.howstuffworks.com/ponzi-scheme3.htm

[10] U.S. Securities and Exchange Commission (2007) Litigation Release No. 20393. https://www.sec.gov/litigation/litreleases/2007/lr20393.htm

[11] Sales, T. (2007) The First Historical Example of a Pyramid Scheme. https://firstclassmlm.com/2007/12/13/the-first-historical-example-of-a-pyramidscheme

[12] Trumbore, B. (n.d.) The Albanian Ponzi Scheme. https://www.buyandhold.com/bh/en/education/history/2010/ponzi scheme.html

[13] Saxon, W. (1985) Enver Hoxha, Mastermind of Albania's Isolation. The New York Times. http://www.nytimes.com/1985/04/12/world/enver-hoxha-mastermind-of-albania-s-isolatio $\underline{\text { n.html?pagewanted }=\text { all }}$

[14] Cani, S. and Hadëri, S. (2002) Sistemi Financiar Shqiptar në Tranzicion: Progres apo Brishtësi? [The Albanian Financial System in Transition: Progress or Fragility?]. https://www.bankofalbania.org/web/pub/cani haderi shq_204_1.pdf

[15] Friedman, T.L. (2007) The World Is Flat: A Brief History of the Twenty-First Century. https://books.google.al/books? $\mathrm{id}=-\mathrm{mv}$ ryTuvo0C\&printsec=frontcover $\# \mathrm{v}=$ onepage\&q\&f=f alse

[16] Elbirt, C. (n.d.) Albania under the Shadow of the Pyramids. http://www.transgallaxys.com/ beo/mlm/albania org.htm

[17] Karafolas, S. and Konteos, G. (2010) Choice of Money Transfer Methods in the Case of Albanian Immigrants in Greece. Transition Studies Review, 16, 962-978. https://doi.org/10.1007/s11300-009-0117-7

[18] Banka e Shqipërisë (1999) Raportivjetor 1998 [Bank of Albania Annual Report 1998]. https://www.bankofalbania.org/web/Raporti Vjetor 1998 2005 1.php 
[19] Halili, P. (2013) 28 Prill 1997, Kërcënimii SaliBerishës “ndezi” mbi 4 mijëlushnjarë, u vranë 9 persona [1997, April 28, SaliBerisha's Threat "Lighted" More than four Thousand People in Lushnja, 9 Persons Were Killed]. Agjencia e Lajmeve Sot News [News Agency Today News].

http://sot.com.al/dossier/28-prill-1997-k\%C3\%ABrc\%C3\%ABnimi-i-sali-berish\%C3\%ABs\%E2\%80\%9Cndezi\%E2\%80\%9D-mbi-4-mij\%C3\%AB-lushnjar\%C3\%AB-u-vran\%C3\%AB9-persona

[20] Halili, P. (2013) 29 marsi, ja si lindën në tënjëjtën ditë 4 firmat e para piramidale [March 29, This Is How Were Created at the Same Day the First 4 Pyramids Firms]. Agjencia e Lajmeve Sot News [News Agency Today News].

http://sot.com.al/dossier/29-marsi-ja-si-lind\%C3\%ABn-n\%C3\%AB-t\%C3\%AB-nj\%C3\%AB jt\%C3\%ABn-dit\%C3\%AB-4-firmat-e-para-piramidale

[21] The World Bank (n.d.) World Bank Open Data. http://data.worldbank.org/

[22] Belova, S. (2015) Russian Ponzi Scheme Creator Claims He Can Influence Bitcoin Economy.

http://www.coinfox.info/news/persons/3647-russian-ponzi-scheme-creator-claims-he-can-i nfluence-bitcoin-economy

[23] Du Preez, E. (2015) Beware of Get-Rich-Quick-Schemes. http://www.fin24.com/Companies/Financial-Services/Scheme-boss-Where-else-can-you-ge t-30-a-month-20150922

[24] Behind MLM (2015) MMM Global Review: Sergey Mavrodi’s MLM BTC Ponzi Cult. http://behindmlm.com/mlm-reviews/mmm-global-review-sergey-mavrodis-mlm-btc-ponzi -cult/

[25] Tolstikova, N. (1999) Mmm as a Phenomenon of the Russian Consumer Culture. European Advances in Consumer Research, 4, 208-215.

[26] Hobson, P. (2015) Russians Warned against Pyramid Schemes as 1990s Fraudster Remerges. The Moscow Times.

https://themoscowtimes.com/articles/russians-warned-against-pyramid-schemes-as-1990sfraudster-remerges-43766

[27] Perlez, J. (1993) Pyramid Scheme a Trap for Many Romanians. The New York Times. http://www.nytimes.com/1993/11/13/business/pyramid-scheme-a-trap-for-many-romanian s.html?pagewanted=all

[28] Smith, A. (2013) Five Things You Didn't Know about Bernie Madoff's Epic Scam. http://money.cnn.com/2013/12/10/news/companies/bernard-madoff-ponzi/

[29] Aol.com (2009) Warning Signs Madoff Investors Ignored. http://www.aol.com/article/2009/03/12/warning-signs-madoff-investors-ignored/1486147/? gen $=1$

[30] Kapri, E. (2008) Piramidat, 133 mijë kreditorë të fajdeve do të tërheqin paratë [Pyramids, 133 Thounds of Pyramids' Creditors Are Getting Refunded]. http://www.arkivalajmeve.com/Piramidat-133-mije-kreditore-te-fajdeve-do-te-terheqin-par ate.46142/

[31] Top-Channel (2014) Tëtjera para nga "Piramidat” [More Money from Pyramid Firms]. http://top-channel.tv/lajme/artikull.php?id=276386

[32] Maho, N. (2014) Zbulohen shifrat: Piramidat, parate qe ndahen per cdo kompani [Pyramids, the Money That Will Get Refunded for Each Firm]. Panorama. http://www.panorama.com.al/zbulohen-shifrat-piramidat-parate-qe-ndahen-per-cdo-komp ani// 


\section{Appendix}

The below Table A1 and Table A2 show the population's involvement and Liabilities/GDP in some countries that have experienced fraudulent schemes ${ }^{1}$.

Table A1. Liabilities per GDP in countries with fraudulent schemes.

\begin{tabular}{cccc}
\hline Countries & Liabilities (in USD Billion) & GDP at market price (in USD Billion) & Liabilities/GDP \\
\hline Albania & 1.2 & 2.36 & $51 \%$ \\
Romania & 1 to 5 & 30.07 & 17 \\
Russia & up to 10 & 395.53 & 3 \\
USA & 65 & 14,720 & 0.4 \\
\hline
\end{tabular}

Table A2. Population's involvement, schemes duration and promised profit from the schemes' starters.

\begin{tabular}{ccccc}
\hline Countries & Starters & Years & $\begin{array}{c}\text { Participation } \\
\text { rate of population }\end{array}$ & Promising profit \\
\hline \multirow{2}{*}{ Albania } & $\begin{array}{c}\text { Sejdia (Largest: Xhaferri, Populli, VEFA } \\
\text { Holdings-most depositors)-25 operators }\end{array}$ & $1991-1997$ & $57 \%$ & up to $40 \% /$ month \\
Romania & Caritas & $1990-1994$ & $13.2 \%$ & $800 \%-3$ months \\
Russia & Mavrodi (MMM) & $1989-1995$ & $6.7 \%-10 \%$ & $\begin{array}{c}20 \%-100 \% / \text { month } \\
(1000 \%-\text { annual })\end{array}$ \\
USA & Madoff & $1992-2008$ & $0.0016 \%$ & $\begin{array}{c}10 \%-12 \% \\
\text { consistently each year }\end{array}$ \\
\hline
\end{tabular}

Table A3. Remittances of Albanian immigrants (in million USD).

\begin{tabular}{ccccc}
\hline Year & Official network & Parallel market & Total & \% of GDP \\
\hline 1994 & 28 & 350 & 378 & 19.4 \\
1995 & 60 & 325 & 385 & 15.5 \\
1996 & 60 & 440 & 500 & 18.6 \\
1997 & 84 & 183 & 267 & 11.6 \\
1998 & 114 & 339 & 453 & 14.8 \\
1999 & 89 & 279 & 368 & 10.0 \\
2000 & 163 & 368 & 531 & 14.3 \\
2001 & 244 & 371 & 615 & 15.2 \\
2002 & 282 & 349 & 631 & 13.9 \\
2003 & 310 & 468 & 778 & 11.4 \\
2004 & 470 & 558 & 1028 & 13.5 \\
2005 & 398 & 600 & 998 & 11.6 \\
2006 & 314 & 860 & 1174 & 13.0 \\
2007 & n.a & n.a & 1297 & 12.0
\end{tabular}

Source: (Karafolas \& Konteos, 2010) [17].

${ }^{1}$ Demographic and economic data source for the countries: (The World Bank, n.d.) [21] Russia:: (Belova, 2015) [22]; (DuPreez, 2015) [23]; (BehindMLM, 2015) [24]; (Tolstikova, 1999) [25]; ( Hobson, 2015) [26] Romania: (Perlez, 1993) [27] USA: (Yang, 2014) [7]; (Smith, 2013) [28] (Aol.com Editors, 2009) [29] Albania: (Jarvis, 1999) [4]. 
Table A4. Total numbers of operators in albania.

\begin{tabular}{|c|c|}
\hline Numbers & Names of operators in Albania \\
\hline 1 & Hajdin Sejdia \\
\hline 2 & Gjallica \\
\hline 3 & VEFA \\
\hline 4 & Populli \\
\hline 5 & Demokracia Popullore-Xhaferri \\
\hline 6 & Kamberi \\
\hline 7 & Cenaj \\
\hline 8 & Silva \\
\hline 9 & Malvasia \\
\hline 10 & Kambo \\
\hline 11 & Grunjasi \\
\hline 12 & Dypero \\
\hline 13 & Bashkimi \\
\hline 14 & Beno \\
\hline 15 & Pogoni \\
\hline 16 & $B \& G$ \\
\hline 17 & Kobuzi \\
\hline 18 & Arkond \\
\hline 19 & Adelin \\
\hline 20 & A.Delon \\
\hline 21 & Agi \\
\hline 22 & Çashku \\
\hline 23 & M.Leka Company \\
\hline 24 & Global Limited Co. \\
\hline 25 & Sude \\
\hline
\end{tabular}

Source: (Halili, 2013) [20].

Table A5. Number of depositors at the time of collapse for major firms.

\begin{tabular}{cc}
\hline Operators & Number of depositors \\
\hline VEFA & 85,000 \\
Gjallica & 82,000 \\
Silva & 15,000 \\
Xhaferri & $1,188,000$ \\
Populli & 304,000 \\
Sude & 13,000
\end{tabular}

Source: (Jarvis, 1999) [4].

Table A6. Payback coefficients announced during 2008 for some operators.

\begin{tabular}{cc}
\hline Operators & Payback coefficient announced \\
\hline Silva & $20.2 \%$ \\
Leka & $34.0 \%$ \\
Cenaj & $11.0 \%$ \\
Glogal Food & $50.0 \%$ \\
VEFA Holding & $11.0 \%$ \\
Gjallica & $2.4 \%$ \\
Kamberi & $10.0 \%$ \\
\hline
\end{tabular}

${ }^{\star}$ Total number of creditors: 133,000 Source (Kapri, 2008) [30]. 
Table A7. Payback coefficients and funds available to the creditors in million Lek announced during 2014 for some operators ${ }^{2}$.

\begin{tabular}{ccc}
\hline Operators & Payback coefficient announced & Funds available in million Lek \\
\hline VEFA Holding & $11.0 \%$ & 403 \\
Silva & $25.2 \%$ & n.a \\
Gjallica & $2.4 \%$ & 425 \\
Kamberi & $7.2 \%$ & 73 \\
Mleka & $34.0 \%$ & n.a \\
Populli & $60.0 \%$ & 28 \\
Xhaferri & $40.0 \%$ & n.a \\
\hline
\end{tabular}

Sources: (Top-Channel, 2014) [31], (Maho, 2014) [32].

\footnotetext{
${ }^{2}$ In 2012, the government passed the law in the Parliament for paying back the depositors of the Albanian fraudulent scheme (from the sale of firms' assets and their blocked bank accounts) through a process, administered from Ministry of Finance. The process is forecasted to end within 10 years from the date that the law will be effective (until 2020). Through the years, several announcements have been issued through media for the depositors to take back a percentage of their investment due to the sale of the firms' assets and their blocked accounts in banks, but the payback process has encountered several problems as many depositors fail to present their original agreements and documents needed. In addition, the payback coefficient announced didn't match with the real percentage of the money that the population took back from their investment (on average less than 10\%) (Table A6 and Table A7). There are still two ongoing cases in the court dealing with the firm's liquidation process.
} 
Submit or recommend next manuscript to SCIRP and we will provide best service for you:

Accepting pre-submission inquiries through Email, Facebook, LinkedIn, Twitter, etc. A wide selection of journals (inclusive of 9 subjects, more than 200 journals)

Providing 24-hour high-quality service

User-friendly online submission system

Fair and swift peer-review system

Efficient typesetting and proofreading procedure

Display of the result of downloads and visits, as well as the number of cited articles Maximum dissemination of your research work

Submit your manuscript at: http://papersubmission.scirp.org/

Or contact ojbm@scirp.org 